\title{
The 1987 ISA Arrests and International Civil Society: Responses to Political Repression in Singapore
}

\author{
MARC RERCERETNAM
}

\begin{abstract}
The penalizing of prominent opposition figures via the Singaporean legal system has made many weary of confronting the ruling People's Action Party (PAP) government on their own turf. Unwilling to take up this challenge, some Singaporeans appear more willing to push for change overseas - beyond the clutches of the PAP government. This article will trace the development of political dissent from abroad and how such actions played a formidable role during the so-called 'Marxist' conspiracy arrests in 1987 and how such alternative political viewpoints will continue to play a large role in shaping criticism and opposition to the present repressive political climate in Singapore.
\end{abstract}

Keywords: Southeast Asia, non-government organizations, Singapore, politics and government, political participation, opposition.

\section{Introduction}

The penalizing of prominent opposition figures via the Singaporean legal system has made many wary of confronting the PAP government on their own turf. Unwilling to take up this challenge, some Singaporeans appear more willing to push for change from overseas - beyond the clutches of the PAP government. While it is undeniable that a considerable number of Singaporeans opposed to the PAP government continue to work for a more open and democratic society from inside Singapore, this paper argues that many people are prepared to take this course of action overseas. By the late 1970s and 1980s, prominent personalities within various expatriate Singaporean communities had already become involved in overseas campaigns, which largely resulted from their own experiences of crackdowns on dissenters, when in Singapore.

Recent academic research in related areas has primarily examined internal aspects of Singaporean civil society. Gary Rodan recently looked at the Singaporean government's efforts not only to control media but 
also to prevent the emergence of organized social and political forces that could lead to a functional civil society (Rodan 2003). Ho, Baber and Khondker have examined the use of information technology and role of the Internet and their implications for the unintended restructuring of Singaporean state and social relations (Ho et al. 2003). Michael Barr has examined the limits of change in Singapore, taking a more positive look at attempts made by the former Prime Minister Goh (1990-2005) in light of the continuing influence of the restrictive influence of Lee Kuan Yew (Barr 2003). In addition, analysis of expatriate Singaporean communities largely focuses on the role of globalization and economic liberalization and how this relates to occupational relocation (Willis and Yeoh 2000; Wan et al. 2003).

To date there has been little research relating to the external aspects involving expatriate Singaporean communities and the role of Singaporean-based civil society outside Singapore. This paper aims to contribute towards the current academic debate on the role of not only domestic but also international civil society and politics in Singapore and Southeast Asia. The primary objective of this paper is to look at how a loose network of Singaporean exiles and expatriates developed as a result of the events of 1987. This event played a major role in arousing suppressed feelings of injustice among a new generation of Singaporeans, many of whom were living or studying outside Singapore at the time. The paper also hopes to shed some light on resistance to PAP regimes by expatriate Singaporean communities and international civil organizations.

\section{Methodology}

There is clearly little official information available on Operation Spectrum1 from the perspective of the Singaporean government. Even the then prime minister, Lee Kuan Yew, amazingly makes only two fleeting references to the whole event in his official memoirs (Lee 2000: 137, 152). Consequently much of this paper is reliant on non-governmental sources such as contemporary pro-detainee publications and on interviews with persons directly or indirectly involved in its events. Many interviewees have preferred to remain anonymous, largely due to a fear of Singaporean governmental direct or indirect reprisals. Many still hold Singaporean passports or are concerned for family members and their financial interests in Singapore.

This paper also highlights the pivotal role played by a group called the Emergency Committee for Human Rights in Singapore (ECHRS). The 
ECHRS newsletter played a disproportionately large role in publicizing the plight of the ISA detainees at the time. Unfortunately much of this publication has been lost, even by its authors, but an almost complete set of copies was found in Kuala Lumpur in 1997 by the researcher, and this gives an accurate political and even chronological analysis of the events. The comprehensive list of supportive organizations in the Appendix was collated from information provided by the ECHRS newsletter.

\section{PAP Attitudes towards International NGOs and Expatriate Singaporean Communities}

The PAP has subtly woven into the Singaporean psyche the myth of Singapore's unnatural existence as a non-Malay, non-Muslim nation-state in a Malay and Muslim region. The implied hostility of this relationship massages the insecurity of the largely immigrant Chinese ethnic majority (76 per cent) and stokes their dependency on the pro-Chinese PAP. As Christopher Lingle insightfully notes, this relationship is 'the outcome of a careful weaving of reality alongside fable' (Lingle 1996: 96). This should not be mistakenly viewed as a uniquely post-colonial phenomenon.

Indeed, these myths can be directly linked to the British colonial period when racial, national and gender identities were manipulated, resulting in an 'inferiority complex' on a national level. For example, racial 'identities' were used by colonial authorities to justify arbitrary action and policy. Racial groupings were conveniently given positive and negative traits, which were in turn used to justify differences in treatment by colonial authorities. This unnatural social climate cultivated a racially charged environment, where different communities were encouraged to compete with each other for the attention of colonial governments and the interests they represented. These supposed identities were never truly challenged even after the departure of colonial governments. Pro-British elites like the PAP, supplanting their colonial rulers, often found it politically useful to maintain existing misconceptions. Consequently racialist social, economic and political policies continue to play an important role in how post-colonial communities rule and perceive themselves (Rerceretnam 2003: 2-3).

Taking into account this Singaporean 'inferiority complex' and 'fear' of outsiders, the PAP has expanded this notion to include the 'incompatible' Western culture into this equation. Christopher Lingle calls this the 'White Peril', which is largely a one-sided projection of images of 'Western decadence' used to prove that liberal democratic ideals can drag 
down the successes enjoyed in Singapore. However, more importantly, international and domestic political opponents are portrayed as 'political lepers' spreading the unwanted proclamations of Western-inspired individual freedoms (Lingle 1996: 38). Within the context of Eastern versus Western, individual versus so-called collective rights, comes the strange paradigm of 'Asian Values' and the justification to ignore some basic democratic and human rights (Rahim 1998: 56).

It is within this larger context that attitudes towards expatriate communities and international civil society should be viewed. Non-government organizations (NGOs) have long been discouraged from taking root in Singapore, based on the premise that 'anyone who wants to make a statement on politics should join a political party' (Chee 1995: 53). As early as 1968, the then Lee Kuan Yew government implemented the amended Societies Act, inherited from the British colonialists, to limit political engagement to groups formally registered with the government for that specific purpose. This stymied collective political expressions outside party politics, making it illegal to do so. As Rodan explains, it also meant that 'opposition political parties and reformist social groups have no legal way of forming alliances or drawing on each other to mobilize support for their causes' (Rodan 2003: 507).

Almost four decades on, few NGOs operate from inside Singapore. The very few that exist work within a very restrictive platform, so as not to annoy the PAP regime. Hence many tend to be largely ineffectual and do not create or play a significant role within Singaporean civil society. The PAP has a very thorny relationship with many prominent international NGOs. Prominent examples of external organizations that challenged the PAP during the 1987 ISA arrests are the World Council of Churches, Asia Watch, International Commission of Jurists (ICJ) and Amnesty International. These NGOs played pivotal roles rallying support for the 1987 detainees. Naturally, NGOs of such ilk find it difficult to gain entry or to operate even on an ad hoc basis in Singapore. An example of this was the denial of the prominent ICJ barrister's access to Singaporean courts to do pro-bono work for an opposition politician (Lloyd-Smith 2002).

There is a strong view among some expatriates and community leaders that the Singaporean embassies and their foreign missions try to control the activities of expatriate communities and their community organizations, be they Singaporean students studying overseas or migrant communities. ${ }^{2}$ Cognisant of their lack of control over expatriate communities, the PAP decided to embark on several initiatives, most 
prominently the formation of the Singapore International Foundation (SIF) in the early 1990s. According to the SIF website, the Foundation aims to 'connect Singaporeans in the international community'. The effectiveness of the SIF is though highly debatable and their influence among expatriate communities overseas is equally questionable. For example, a community leader based in Australia claimed that no one knows of or has contact with the SIF in Australia. This author strongly feels this to be the case in many countries. ${ }^{3}$

Hence, while the PAP may enjoy almost complete control of social, economic and political facets of Singaporean life, the same cannot be said of expatriate communities and foreign-based NGOs. The PAP's control of NGOs and especially foreign-based student groups and community organizations, was and is sporadic at best.

\section{Resistance in an Authoritarian Landscape}

In addition to the notorious Internal Security Act (ISA), which allows for detention without a judicial trial, citizens fear that any criticism directed towards the PAP will be punished in ways that can directly affect their income or way of life (Selvan 1990: 300). Challenging the status quo is therefore not an option open to the vast majority of people.

By the late 1970s, the PAP government adopted a more discreet line of attack against its local critics: the state-controlled judiciary came to be used, via spurious defamation suits, to discredit and more importantly to bankrupt opponents. This tactic was so successful that the PAP government even began using it against international publications like Newsweek, Far Eastern Economic Review, Asian Wall Street Journal, Time, The Economist and the International Herald Tribune (Chee 2001: 173-80). By the 1980s most elements of resistance to the authoritarian rule of Lee Kuan Yew and the People's Action Party (PAP) had been largely neutralized. The political outlook and any ensuing responses by the ordinary Singaporean citizenry was at best muted.

The fear of governmental retribution was constant. Consequently many felt the price for dissension was far too high and accepted whatever conditions were dealt to them. Singaporeans felt the PAP's political, social and financial power very deeply. The whole process was primarily an 'interaction' between the 'powerful' and the 'powerless' (Foucault 1980: 119). Put simply, what was gained from this 'interaction' was employment and a standard of living unattainable in any other Southeast Asian country. 


\section{Political Purges}

Political purges in post-independence Singapore occurred throughout the 1960s, 1970s, 1980s and most recently in 2002. The infamous 'Operation Cold Store' ISA arrests of February 1963 showed how the PAP government, with the support of the British authorities, was prepared to take any and all measures to curtail political threats, no matter how legitimate.

In contrast to the earlier ISA arrests, the purge of 1987 acted as a catalyst for local and expatriate Singaporeans alike and their many overseas supporters to challenge the PAP's anti-democratic hegemony. The strong international interest shown during the 1987 ISA arrests compares markedly to other PAP crackdowns past and present. Even the recent use of the ISA in 2002 to arrest 21 alleged terrorists did not stir similar levels of protest, despite the fact that the government has made no attempt to prove their case in a court of law.

There is one striking difference between the 1987 ISA detainees and their counterparts that came before or after them: the latter appeared not to have strong links with regional or international organizations. For example, detainees from 'Operation Cold Store' were primarily local trade unionists, opposition politicians, student and civic groups (Minchin 1986: 127-28). The recent 2002 arrests were centred around Muslim-based groups, arguably with limited connections to influential NGOs. This problem is compounded by the prevailing anti-Islamic, post-9/11 environment which discourages support for such groups (Rahim 2003: 209).

\section{Conditions Leading up to 1987}

By the 1980s, major changes were taking place regionally. Regional perceptions and concerns began to widen and become more inclusive. This worked hand in hand with the emergence of NGOs in many countries in the region. By the 1980s, modern media such as television, video and facsimile machines were cheaper and international telephone services accessible. Back in the early 1960s, such aids to communication were but a 'pipedream' for many an activist. The accessibility to new communications technology helped various advocates create and strengthen links outside their domestic circle. These links played a pivotal role in the protest campaign against the 1987 ISA arrests.

In addition to this, many of the 1987 ISA detainees were English-language proficient and professionally trained; indeed, some had worked 
in regional NGOs in places like Hong Kong. Many also personally knew or were acquainted with earlier groups of exiles like Tan Wah Piow who lived in western Europe. ${ }^{4}$

\section{Background to the 1987 'Marxist Conspiracy'}

In May 1987, Singapore's Ministry of Home Affairs (MHA) claimed that a 'Marxist conspiracy' threatened to overthrow the Singapore government. They claimed arrests had averted this international conspiracy, based in London, to establish a communist state in Singapore (Straits Times [hereafter ST], 27 May 1987). The accused 'leader' of this scheme was Mr Tan Wah Piow, who at the time was living in London. His Singaporean agent was reported Mr Vincent Cheng, a lay worker in the local Catholic church. Together Tan and Cheng reportedly controlled a network of idealistic agents that extended far beyond Catholic Church circles. This included a number of solicitors, former UK-educated returned students and therefore associates of Tan Wah Piow in London, some student activists, and persons connected with local drama circles (ST, 27 May, 21 June, 20 July 1987).

\section{ISA Arrests: Initial Reactions}

The arrests began in the early hours of the 21 May 1987, and within weeks 22 people had been detained, for varying periods of time. Most were social workers, dramatists, and Catholic Church welfare workers, detained on the pretence that they were part of a 'Marxist conspiracy' intent on overthrowing the government (ECHRS, 20 July 1987: 7; Seow 1994: 67). While there is little doubt that the 1987 arrests had a big impact on the lives of the detainees and their families and friends, its influence was felt much farther afield than this. Outside Singapore a myriad of individuals, informal groups and NGOs for the first time found themselves united by a common cause.

Overseas attention was particularly strong in the 1987 arrests, compared to arrests in the 1960s, 1970s and early 1980s. Major regional publications such as Asia Week, Far Eastern Economic Review and even the Kuala Lumpur-based The Star newspaper followed the ISA arrests very closely. Articles in these publications were generally critical of the PAP government and cynical of the Marxist allegations, as many were in fact practising Christians. A mere five weeks after the initial arrests, then foreign minister S. Rajaratnam complained that over 200 organiza- 
tions from around the world had sent protest letters to the government (ECHRS, 31 August 1987: 3).

Apart from the very active role played by detainee support groups and several opposition political parties in Singapore, overseas Singaporeans, small and large international groups, and even Malaysians (their support predates the Malaysian government's own detentions several months later) played a disproportionately large role in highlighting and publicizing the inequities of the PAP government arrests. Why did foreign organizations and expatriate Singaporean communities play such a prominent role?

\section{Previous Political Purges and the Development of a Loose Network of Singaporean Exiles}

Former student leaders of the University of Singapore Students' Union from the early 1970s, some of whom had been implicated as ringleaders of the 'Marxist conspiracy', were instrumental in drumming up opposition to the Singaporean government during the 1987 arrests. Mr Tan Wah Piow, long exiled in London, Mr Tsui Hon Kwong, in Hong Kong, and several other ex-student union activists living in the Netherlands and France acted as catalysts for the growing resistance to the PAP government. ${ }^{5}$ This network formed in response to the 1987 arrests was named the European Committee on Human Rights in Malaysia and Singapore or 'Kehmas' for short. According to the Netherlands-based International Institute of Social History website, Kehmas was initiated as part of a Malaysia/Singapore workgroup, the latter group set up in $1974 .{ }^{6}$

Unlike earlier political purges, this group of tertiary-educated individuals was more professionally mobile in comparison to their earlier political counterparts. Over the years, many relocated to First World countries where they established themselves professionally. Tan Wah Piow played a prominent role in arousing pro-democratic sentiments when he fled to London in the mid-1970s. According to one interviewee who was a UK-based student at the time, Tan loomed large over progressive circles in the Singaporean and Malaysian student communities of the day. ${ }^{7}$ The trend continues with the likes of Mr Tang Liang Hong in 1997 and Mr Zulfikar Mohamad Shariff in 2002 (Straits Times Interactive, 24 July 2002).

A large number of past and present activists continue to make an effort to leave Singapore, even for a short period of time, usually for further studies or employment. This constantly feeds small but grow- 
ing enclaves of anti-PAP resistance in the Asia-Pacific region, the USA and Europe.

So far we have discussed secular-based opposition to the PAP; however the issue of religious opposition, particularly from the Roman Catholic Church, should be taken seriously. The borderless nature of any international belief system must worry the PAP government immensely. Unlike a religion, the control of the PAP government is confined to the limits of its small 660 square kilometre island. In contrast, the reach of organized religions like that of the Roman Catholic Church is global, therefore the PAP control of Singaporeans could be tenuous in some scenarios. In addition, the solidarity that came to the fore during the 1987 ISA arrests, including support from other non-affiliated Christian groups, shows that religion is a force to be reckoned with.

More significantly, the line between religion and secularism appeared rather blurred among prominent people involved in the 1987 ISA arrests and their support groups. While many had a strong belief system based on religious doctrine and teachings, they also appeared to be strongly rooted in the realities of modern secularist society. This multifaceted approach gave them a formidable advantage and shows clearly through the substantial support accorded to them in the aftermath of the arrests in May 1987.

\section{The Rise of an Outspoken, English Language-Proficient Middle Class}

The economic ascendancy of Singapore in the 1960s brought in its wake a new affluent generation in the 1970s and 1980s. For example, between 1960 and the 1992, the per capital gross national product increased seventeen fold (Rodan 1996: 19). By 1988, 503 respondents to a press survey claimed to identify themselves as 'middle class' - statistically 75 per cent of Singaporeans ${ }^{8}$ (Rodan 1996: 29). Indeed, Lee Kuan Yew acknowledged in 1987 that 'our society has become 80 per cent middle class' (Rodan 1996: 30). Unlike their parents, this new generation looked to other areas for socio-economic and political inspiration. Familiarity with post-colonial concepts of equality, justice and democracy played a large role in how many comprehended the world around them.

Despite government policies that economically, socially and politically segregated communities along racial lines, among the English-educated middle classes, issues such as race, religion, language or gender were to some extent losing their significance in post-colonial Singapore. Growing 
economic success in the Southeast Asia region in a similar way broke down barriers between fellow regional, middle-class compatriots. This led many to question the contradictions and inequities long accepted by previous generations.

With economic success in Singapore and the rise of the new middle class, many families found they could afford to send their children to study abroad. The popularity of overseas tertiary studies in the 1980s coincided with the commercialization of education in many Englishspeaking Western countries. The USA, Canada, the United Kingdom, Australia and New Zealand were (and still are) the countries of choice for tertiary education (Mazzarol and Hosie 1999).

Misgivings about the Singaporean tertiary educational system, plus the high government-imposed second-language requirements for acceptance into local universities, forced many more abroad. More importantly when based overseas, many Singaporeans began to see through the naïve PAP view of society and the world. Away from the constrained Singapore media, government infrastructure and political system, they began to see gaping holes in the traditional authoritarian rationale of Lee Kuan Yew's PAP. ${ }^{9}$

When abroad many young Singaporeans found themselves left in a much more politically plural, multicultural, multinational and multiracial environment than in Singapore. Their social circles, while still often within the context of a local Singaporean student clique, often included students from Southeast Asia or the wider Asian region. This inculcated a new affinity between students, inspiring a pan-Asian identity on campus. Unfettered by the real or imagined prying eyes of the police and ISD, and inspired by youthful optimism and exuberance, some began working (to varying degrees) in support of causes outlawed or frowned upon at home.

\section{Western Colonial Cultural Barriers Crumble Away in the 1980s}

In the 1980s massive changes were taking place in countries such as Australia, Canada, New Zealand, the UK and the USA. Large-scale immigration from the Asia-Pacific region began in earnest around this period, and this facilitated the dismantling of long-held barriers to socialization with persons of Asian descent. It was also during this period that local community and political organizations began taking an interest in the region and began supporting pro-democracy causes. 
The interaction between the host countries and the overseas student communities played a very important role in influencing Singaporean and other overseas students. Political views, lifestyles, philosophies and practices were adopted and brought back to Singapore.

\section{Use of New Technologies}

In the 1980s new technologies that facilitated global communication were fast become affordable. Fax machines, videos, personal computers/word processors and cheaper direct dialling phone services were now far more accessible to students and community organizations alike. Many student groups also had easy access to university-funded facilities. Local student government bodies were often very supportive and would not only provide political support but also give open access to a full range of modern office, telecommunications and even sometimes TV and radio facilities.

A perfect example of this was a publication called the Emergency Committee for Human Rights in Singapore. This fortnightly newsletter was relayed around the world via a simple office fax machine from Christchurch in New Zealand and was one of the main sources that helped garner international support for the 1987 detainees.

In Australia local Singaporean support groups such as the Network of Overseas Students Collective in Australia (NOSCA) enjoyed extensive use of university union facilities. Facsimile machines, photocopying and computer-based desktop publishing technology allowed for the rapid production of high-quality literature, publications and media releases. This helped facilitate the organizing of public meetings and the co-ordination of protest actions in support of the ISA detainees.

\section{Internationalization of Non-Governmental Organizations}

The broadening outlook of the professional and middle classes in the 1980s was facilitated by the concept of the 'Pacific Community', which gained popularity mainly via governmental, business and intellectual circles. This vernacular naturally seeped into community circles soon after and was taken up in earnest by some non-governmental organizations (NGOs) based in various capital cities in the region. Growing regional economic success brought with it greater economic interdependence between communities, which in turn fuelled local versions 
of regionalism (Yamamoto 1995: xi). In this new climate and driven by the new professional and middle-class communities, many new and existing NGOs formed linkages that formerly would not have been possible, due to differing nationalist or domestic concerns. However by the 1980s, these concerns began to encompass issues outside traditional boundaries. This new incipient NGO movement helped to highlight the plight of the Singaporean detainees in 1987.

This paper has compiled a list of organizations and influential individuals that officially supported the 1987 ISA detainees. To date a total of 64 organizations and opinion makers have been identified - many ad hoc organizations alongside more established religious, academic, governmental, student and professional bodies; these are listed in the Appendix to this paper. This list should however be much longer. As pointed out earlier in this article by the then foreign minister $S$. Rajaratnam, probably well in excess of 200 organizations and individuals sent protest letters to the government of the day. As the PAP government presently holds this information, there is little likelihood of this listing ever being made public.

\section{Who Were These Groups?}

The groups and individuals contained in the listing (see Appendix) can be broken down into six broad categories; Ad hoc, Church, Student, Professional, Governmental/Political groups, and miscellaneous entries for groups and individuals.

\begin{tabular}{|l|c|}
\hline Ad hoc groups & 3 \\
\hline Church groups & 20 \\
\hline NGOs & 20 \\
\hline Student groups & 5 \\
\hline Professional/academic & 6 \\
\hline Government/political groups & 4 \\
\hline Miscellaneous entries for groups and individuals & 10 \\
\hline
\end{tabular}

There are far too many organizations to examine individually, so this paper will be picking out specific organizations that played a significant role at the time. ${ }^{10}$ 


\section{Ad Hoc Groups}

These groups were set up to address the 1987 ISA arrests and in most cases were disbanded soon after 1988. They were located in Malaysia, Philippines, Kyoto, Hong Kong, Sydney and various west European cities. However, the more prominent groups appeared to be operating out of Europe, Sydney, Hong Kong and Malaysia.

In this category the Emergency Committee for Human Rights in Singapore (ECHRS) played a disproportionately large role in publicizing the plight of the ISA detainees. The ECHRS was based in Christchurch, New Zealand and published a fortnightly newsletter between 26 May 1987 to (approximately) 3 October 1988. According to one interviewee, this Christchurch-based group were 'friends' with some of the ISA detainees. However, this was definitely not their sole motive for support. They apparently had strong views on the poor state of human rights and democracy under the PAP government. The ECHRS was funded by a Church organization, probably the Christian Conference of Asia, which was later expelled from Singapore in December 1987.11

Another group worthy of mention is 'Kehmas'. According to interviewees, this group was set up solely in response to the 1987 ISA arrests. The group was established jointly by Mr Tan Wah Piow, the supposed 'ringleader' of the accused Marxist plotters, and several other pro-democracy Singaporeans based in various European cities. According to the PAP government, Tan master-minded the 'Marxist conspiracy to subvert the existing social and political system in Singapore through communist united front tactics to establish a communist state' (Seow 1994: 69). Despite its ad-hoc beginnings, 'Kehmas' was still active on indigenous Penan issues as late as 1992.

\section{Church Groups}

Numerically the largest group in this list is that of Church-based organizations; a total of 19 altogether. Malaysian church leaders were quick off the mark with a pastoral letter (2 June 1987) signed by the three Malaysian bishops supporting their Singaporean counterparts' right to involve themselves in social and economic matters. ${ }^{12}$

Support from this category was extensive with protest letters coming from the Hong Kong, South Korea, New Zealand, the UK, Australia, Philippines, Sri Lanka and Japan. 


\section{Non-Government Organizations (NGOs)}

These groups played a significant role in publicizing and highlighting the unlawful nature of the arrests. For example, various Amnesty International offices 'adopted' 12 Singaporean detainees as 'Prisoners of Conscience'.

The International Commission of Jurists (Geneva), the International Federation of Human Rights (Paris) and the Asian Human Rights Commission (Hong Kong) were part of a prominent international delegation calling itself the International Mission of Jurists. They collectively went to Singapore between 5 and 9 July 1987 to investigate circumstances surrounding the arrests. ${ }^{13}$ Such initiatives by prominent professional and NGO bodies helped embarrass the PAP government internationally.

\section{Student Groups}

The student groups appeared to be mainly based in Sydney, Australia and Cambridge (UK). The Cambridge University-based Singaporean student group was still active in the early 1990s and was described by a contemporary as primarily being a political discussion group. However, a protest letter was sent by the Cambridge University Students Union not the Singaporean student group. One can only assume the issue was put to the student union by its Singaporean members.

In Sydney, various Singaporean and Malaysian student groups appeared more willing to directly express disapproval at the 1987 ISA arrests. The Network of Overseas Student Collectives in Australia (NOSCA) also known as the Overseas Student Collective (OSC) was set up by two Malaysian architecture students at the University of NSW in 1980. For the next five years the group was, like its Cambridge University counterpart, a rather ineffectual discussion group. However, by the mid-1980s the group began to grow in size and influence. NOSCA did not limit itself to Malaysian or Singaporean issues and adopted a very regional perspective, cultivating extensive links with regional NGOs, international activists groups and other like-minded Australian organizations. NOSCA was involved in campaigns on environmental deforestation and human rights in Malaysia, China, Indonesia and the Philippines. They also advocated against the exploitation of foreign students, particularly in substandard Australian private 'colleges', and were supportive of local Australian Aboriginal communities during the bicentenary celebrations in 1988.

NOSCA organized its activities via various Sydney-based student union groups at Sydney University, the University of New South Wales 
and the New South Wales Institute of Technology (later renamed the University of Technology, Sydney). Between 1987 and 1988, the group held numerous public meetings on the 1987 ISA arrests, produced literature, ran media campaigns and also lobbied student organizations and Australian politicians in support of the detainees. During this period NOSCA formed the Malaysia Singapore Human Rights Commission, which was utilized as a body to address the ISA arrests in Singapore and the later arrests in Malaysia the following year.

In 1989, NOSCA even 'crashed' an informal Singaporean expatriate buffet attended by the then Brigadier-General Lee Hsien Loong (now prime minister) at the former Regent Hotel at Sydney's cities Circular Quay district. A few non-Singaporean supporters unknowingly handed anti-ISA leaflets to the younger Lee and chanted anti-PAP slogans very much to the embarrassment of Lee and the embassy staff. ${ }^{14}$

\section{Miscellaneous Entries for Groups and Individuals}

This group was difficult to categorise as many were simply identified ambigiously as a set of unidentified groups or a collection of individual from a larger body. For example, 55 members of the United States Congress 'condemning the detentions' was reported in December 1987. In another case, 'one third' or 34 members of the New Zealand Parliament 'expressed ... extreme concern' in April 1988. ${ }^{15}$ In other examples 14 members of the Japanese Diet and 39 'legal academics and lawyers' from the United Kingdom, Australia and New Zealand signed a letter opposing the arrests. ${ }^{16}$

\section{Conclusion}

This paper has sought to demonstrate how the ISA arrests of 1987 acted as a catalyst for local and expatriate Singaporeans and their supporters, to challenge the PAP's anti-democratic hegemony. Unusually intense international interest shown during the 1987 arrests compares significantly to other PAP political crackdowns, past and present. The circumstances surrounding this event had one distinct difference in comparison to earlier political purges. International support was much easier to garner after the 1980s, owing to a growing climate of regionalism. Linkages between different NGOs pushed many to encompass issues outside their traditional boundaries. The associated groups and arrestees had strong links with regional and international organizations. Even recent ISA arrests, such as the one involving the accused 
Jemaah Islamiyah (JI) conspirators in 2002, judging by international reactions, arguably have limited connections to influential NGOs.

It is difficult to accurately measure the influence of NGO actions in the wake of the 1987 ISA arrests. It is undeniable, judging by the sheer weight of criticism levelled by a large number of NGOs and other organizations that there was a massive sea change in how such issues were perceived internationally.

Taking into account the ineffectual status of indigenous NGOs as a result of the amended Societies Act (1968), the ensuing pressure placed on the PAP government showed that expatriate communities, when working together, can wield considerable political clout. These internationally based communities were outside the control of the PAP regime and played a strong role in pressuring the regime. For example, student groups such as the NOSCA worked from different Sydney-based university campuses'. Similarly, Khemas - a collection of Singaporean activists and dissidents then based across western Europe - criticized and questioned the legitimacy of claims made by the PAP regime. And last but not least, the Emergency Committee for Human Rights in Singapore (ECHRS), based in New Zealand, was the primary source of information for the international press and NGOs.

The PAP, cognisant of their worsening state of control, especially over expatriate Singaporean communities, launched a programme to strengthen vital links. It is noteworthy that these linkages are supervised largely through their foreign embassies or consulates. For example, the Singapore International Foundation (SIF) was set up to 'connect' with Singaporean communities overseas. It is more likely, judging from the PAP's poor public relations experience during the 1987 arrests, that their primary aim was also to monitor, influence and where possible attempt to control expatriate Singaporean communities. However judging from feedback from some present-day community leaders, to date these initiatives appear to have been rather ineffectual.

Apart from the fundamental changes to the regional political landscape, the 1987 ISA campaigns were aided by several other important elements. Accessibility to new media-related technology, the upsurge in social and economic mobility among dissenting professionals, a growing acceptance of democratic ideals, the breaking down of traditional cultural and language barriers, and the increasing awareness by host communities of foreign issues such as the 1987 arrests, helped strengthen opposition to the PAP regime. 
Hence while the PAP may enjoy almost complete control within the island state, this does not apply to expatriate Singaporean communities and sympathetic, foreign-based NGOs. Judging by the outcomes from the 1987 ISA arrests, the PAP's control of NGOs, and especially foreignbased student groups and community organizations, has proved to be sporadic and ineffectual.

Dr Marc Rerceretnam is a research academic at the University of Western Sydney, Australia.

\section{APPENDIX: \\ List of organizations that officially supported the 1987 ISA detainees.}

The following information was collated from various issues of the

'Emergency Committee for Human Rights in Singapore', published from 26

May 1987 to 3 October 1988 and from observations made by interviewees.

1. Emergency Committee for Human Rights in Singapore (Christchurch, New Zealand)

2. Human Rights Support Group for the Singapore 18 (M'sia)

3. Christian Conference of Asia (based in Singapore, expelled on 30 Dec. 1987)

4. Archbishop of Malaysia, Soter Fernandez (M'sia)

5. National Union of Journalists (M'sia)

6. Free Singapore 16 (Philippines)

7. Perak Education and Research Assoc for Consumers (M'sia)

8. various Catholic organizations and regional Asian organizations (Hong Kong)

9. ' 9 human rights, religious affairs and student work led by ... lawyer Mr Thongbai Thongpao" (Thailand)

10. 'Churches and ecumenical bodies ... coalition of lawyers, academics and community leaders' (Kyoto, Japan)

11. National Council of Churches (S Korea)

12. Network of Overseas Students Collectives in Australia (also known as the Oversea Student Collective) (Sydney, Australia)

13. UTS SA Overseas Student Dept (Sydney, Australia)

14. UNSW SU Overseas Student Services (Sydney, Australia)

15. Sydney University SRC Overseas Student Dept (Sydney, Australia)

16. Malaysian \& Singaporean Human Rights Commission (Sydney, Australia)

17. National Council of Churches (NZ)

18. Catholic Commission for Evangelisation, Justice \& Development (NZ)

19. University of Auckland, Law faculty (NZ)

20. University of Canterbury, Law faculty (NZ)

21. American Friends' Service Committee (Hawaii, USA)

22. AsiaWatch (Washington, USA) 
23. National Council of Churches (New York, USA)

24. Amnesty International (London, UK)

25. 'various Church groups' (London, UK)

26. International Commission of Jurist (Geneva, Switzerland)

27. International League of Human Rights (Paris, France) ${ }^{17}$

28. Australian Catholic Bishop George Pell (Melbourne, Australia)

29. Australian Anglican Archbishop David Penman (Melbourne, Australia)

30. Kansai Emergency Committee on Human Rights in Singapore (Kyoto, Japan)

31. International Mission of Jurist;

- ICJ (Geneva)

- International federation of Human Rights (Paris)

- Asian Human Rights Commission (HK)

- Lawasia (Sydney) ${ }^{18}$

32. Tan Sri Dr Tan Chee Koon, ex-leader of Msian parliamentary opposition (M'sia)

33. Japan Civil Liberties Union

34. 'eight legal academics and lawyers from Australia' (Australia)

35. Philippines Catholic Bishop Francisco Claver (P'ppines)

36. Friends of Singapore (HK)

37. Presbyterian Church (Atlanta, USA)

38. Bishop Bede Heather (Parramatta, Sydney, Australia) ${ }^{19}$

39. National Council of Churches of Christ (USA)

40. Church Committee for Human Rights in Asia (Chicago, USA)

41. Harvard University Alumni (USA)

42. '30 religious ... women's, peasants', workers', development, media, theatre, and civil rights groups' (Sri Lanka)

43. Christian Workers' Fellowship (Sri Lanka)

44. Archbishop of Perth, Most Rev W Foley (Perth, Australia)

45. CORSO $(\mathrm{NZ})^{20}$

46. '14 members of the Japan Diet' (Japan) ${ }^{21}$

47. '39 legal academics and lawyers from the UK, Australia and New Zealand signed a letter' (Aust, UK, NZ) ${ }^{22}$

48. Amnesty International (Fitzwilliam College, Cambridge Uni, UK)

49. Cambridge University Students' Union (Cambridge, UK)

50. US Dept of State

51. Amnesty International (Saskeatchewan/Ontario/Winnipeg, Canada)

52. 'letters signed by 55 members of Congress condemning the detentions' (USA) ${ }^{23}$

53. 'One third ... NZ Parliament (34 MPs) ... expressing ... extreme concern' (NZ)

54. Amnesty International (Canada)

55. Amnesty International (Hong Kong) ${ }^{24}$

56. American Bar Association (USA)

57. The Lawyers' Committee for Human Rights (USA)

58. Nelson Riis, New Democrat House Leader (Canada)

59. S'pore and M'sian British Association SIMBA (UK)

60. 'Tokyo's Catholic Community' (Japan)

61. The National Christian Council in Japan (Japan)

62. International Young Christian Workers (HK)

63. Korea Christian Action Organisation (S Korea) ${ }^{25}$ Khemas (various European cities) 


\section{NOTES}

1 'Operation Spectrum' is the official name given by the PAP government to the ISA arrests in 1987.

2 Interview with Mr M. [anonymous], 9 August 2004; interview with Mr Lim Teik Hock, 20 August 2004.

3 Interview with Mr Lim Teik Hock, 20 August 2004.

4 Interview with Ms Y. [anonymous], 4 July 2004, Sydney.

5 Interview with Ms Y. [anonymous], 4 July 2004, Sydney.

6 Mehmet Bilgen, undated, accessed 16 October 2004.

7 Interview with Mr Lim Teik Hock, 20 August 2004, Sydney.

8 The general conception of the middle classes being; earning at least $\$ \$ 2,000$ per month, owning a three- or four-bedroom flat, and having a person in the family with a tertiary education.

9 Interview with Mr M., 2 January 2006.

10 These organizations were categorized according to their affiliations. Much of this information was provided in the ECHRS newsletter and where not forthcoming, was backed up via Internet searches for the purposes of this study. After two decades, many listed organizations no longer exist; however their names indicate their purpose or affiliation.

11 Interview with Ms Y. [anonymous], 4 July 2004, Sydney, Australia.

12 'Marxist Plot Revisited: Reactions of the Church in Singapore'. Accessed 16 Oct. 2004: singapore-window.org/sw01/010521m3.htm.

13 Ibid.

14 Interview with Mr M. [anonymous], 9 August 2004, Sydney, Australia.

15 ECHRS, 21 December 1987: 9-12 and 25 April 1988: 6-9.

16 ECHRS, 31 August 1987: 3 and 2 October 1987: 3.

17 ECHRS, 13 June 1987: 3-6.

18 ECHRS, 2 July 1987: 3.

19 ECHRS, 15 July 1987: 2-9.

20 ECHRS, 12 August 1987: 6-9.

21 ECHRS, 31 August 1987: 3.

22 ECHRS, 2 October 1987: 3.

23 ECHRS, 21 December 1987: 9-12.

24 ECHRS, 25 April 1988: 6-9.

25 ECHRS, 3 October 1988: 9-12.

\section{REFERENCES}

Barr, M. 2003. 'Perpetual Revisionism in Singapore: the Limits of Change'. The Pacific Review 16 (1). London: Taylor \& Francis.

Bilgen, Mehmet. 'Plaatsingslijst van het archiefvan de Werkgroep Maleisie/Singapore 196097', International Institute of Social History (Amsterdam), undated. Accessed 16 Oct. 2004 at: http:/www.iisg.nl/archives/html/w/10822349/108223490.html.

Chee, Soon Juan. 1995. Singapore My Home Too. Singapore: Chee Soon Juan.

- 2001. Your Future, My Faith, Our Freedom. Singapore: Open Singapore Centre.

Emergency Committee for Human Rights in Singapore (ECHRS), various newsletters, 26 May 1987 to 3 Oct. 1988, Christchurch, New Zealand.

Foucault, Michel. 1980. 'Truth and Power'. In M. Foucault, Power? Knowledge: Selected Interviews and Other Writings, 1972-77,ed. C. Gordon. New York: Pantheon Books. 
Ho, K. C., Baber, Z. and Khondker, H. 2003. 'Sites of Resistance: Alternative Websites and State-Society Relations'. British Journal of Sociology. 153(1). London: Taylor \& Francis.

Lee Kuan Yew. 2000. From First World to First: The Singapore Story: 1965-2000: Memoirs of Lee Kuan Yew. Singapore: Singapore Press Holdings and Times Editions.

Lingle, Christopher. 1996. Singapore's Authoritarian Capitalism. Barcelona: Ediciones Sirocco.

Lloyd-Smith, Jake. 2002. 'QC Critic of Judicial System Barred from Defending Opposition Leader'. South China Morning Post, 11 January.

'Marxist Plot Revisited: Reactions of the Church in Singapore' Accessed on the Singapore Window website. Accessed 16 Oct. 2004 at: www.singapore-window. org/sw01/010521m3.htm

Mazzarol, T. and Hosie P. 1999. Australia and New Zealand: Rivals or allies? Strategic Marketing Issues in International Education, Paper presented to the HERDSA Annual International Conference, Melbourne, 12-15 July.

Minchin, James. 1986. No Man Is an Island: A Study of Singapore's Lee Kuan Yew. Sydney: Allen \& Unwin.

Rahim, Lily. 1998. 'In Search of the Asian Way: Cultural Nationalism in Singapore and Malaysia'. Commonwealth and Comparative Politics 36 (3) Nov. London: Frank Cass.

- 2003. 'The Road Less Travelled: Islamic Militancy in Southeast Asia'. Critical Asian Studies 35 (2). London: Routledge.

Rerceretnam, Marc. 2003. Black Europeans, the Indian Coolies and Empire. Sydney: Sydney University $\mathrm{PhD}$ thesis.

Rodan, G.1996. 'Class Transformations and Political Tensions in Singapore's Development'. in R. Robison and D. Goodman (eds), The New Rich in Asia. London: Routledge.

- 2003. 'Embracing Electronic Media but Suppressing Civil Society: Authoritarian Consolidation in Singapore'. The Pacific Review 16(4). London: Taylor and Francis.

Selvan, T. S. 1990, Singapore the Ultimate Island: Lee Kuan Yew's Untold Story, Melbourne: Freeway Books.

Seow, Francis T. 1994. To Catch a Tartar: A Dissident in Lee Kwan Yew's Prison. New Haven, CT: Yale University Southeast Asian Studies.

- 1998. The Media Enthralled: Singapore Revisited. Boulder, CO: Lynne Rienner Publishers.

Straits Times. 27 May 1987; 21 June 1987; 20 July 1987.

Straits Times Interactive. 2002. 'Singapore Muslim Activist Flees to Australia'. 24 July.

Wan, D., Hui, T. K. and Tiang, L. 2003. 'Factors Affecting Singaporeans' Acceptance of International Postings'. Personnel Review 32 (6).

Willis, K. D. and Yeoh, B. S. A. 2000. 'Gender and Transnational Household Strategies: Singaporean Migration to China'. Regional Studies 34(3).

Yamamoto, Tadashi (ed.) 1995. Emerging Civil Society in the Asia Pacific Community Singapore: ISEAS. 